IJTC

Ilomata International Journal of Tax \& Accounting

P-ISSN: 2714-9838; E-ISSN: 2714-9846

Vol. 1 No. 4 October 2020 pp.179-184

https://www.ilomata.org/index.php/ijtc

\title{
Application In Activity Based Costing (ABC) Calculation Of Home Development Cost (Study on Housing in Sidoarjo)
}

\author{
Hendra Dwi Prasetyo ${ }^{1}$, Kusuma Adi Rahardjo ${ }^{2}$, Iman Supriadi ${ }^{3}$ \\ Nindya Kartika Kusmayati ${ }^{4}$, Moh Wahib ${ }^{5}$ \\ ${ }^{12345}$ Mahardhika Surabaya High School of Economics \\ correspondent: hendra prasetya@ymail.com
}

Submitted : August 3,2020 Revised : September 25, 2020 Published : October 30, 2020

\begin{abstract}
Activity based costing (ABC) is an improved system of the traditional one. This system is calculating costs that provide accuracy and relevance in allocating overhead costs. This system has an overall cost tracking compared to traditional systems. This research uses a descriptive method of case study approach, which can describe the existence of a variable, symptom or condition. Using this method adjusts the ability to answer the problem under study and hopes to be able to provide clear results and answers. The results of the calculation of housing construction cost using the ABC system on housing in Sidoarjo are able to describe results more accurately and do not cause distortion of costs.
\end{abstract}

Keywords : production cost, traditional systems and $\mathrm{ABC}$ systems

\section{INTRODUCTION}

Every company always calculates profit in production. To achieve company goals in general need to pay attention to company policy. To be able to achieve the company's goals in increasing profits, companies must properly pay attention to the costs incurred for production and determining the selling price. Mismatched selling prices can affect the company's finances. Marketing is not optimal and the amount of inventory will have an effect on company revenue. The role of production cost is very important in determining the selling price of the product. Calculating production cost is all production costs used to process raw materials into finished goods within a certain period. The cost of production is the basis for determining selling prices and profits and as a measurement tool.

Activity based costing is an improved system of the traditional one, this system is calculating costs that provide accuracy and relevance in allocating overhead costs. This system has an overall cost tracking compared to traditional systems. The growing business as it is today is not only limited to the benefits of $\mathrm{ABC}$ for information on production costs but also as a concept that is broadly interpreted as information to motivate personal in improvising the process to produce products or services for customers. This system is useful for overcoming the weaknesses of traditional systems made specifically by industrial companies in Martusa et al. (2010).

Research conducted by Joseph et.al. (2019) had given result, that modern costing such as Activity Based Costing systems can optimize the benefits of techniques that enable them to identify, accumulate and manage the costs of company activities to ensure accuracy in decision making and produce business excellence and customer satisfaction. Al-Saidi's research (2014) results are the need for multi item success steps because they capture individual perceptions more efficiently, unlike single item sizes that do not measure the complex nature of ABC system 
success, multi items use composite scores to measure and analyze success by providing the biggest explanation of the factors determining the application of ABC. There is also research by Farzaneh et.al. (2010) show the results that cost of goods sold is not consistent with the rigidity of the cost model, but in general, administrative and sales costs are inherent in changes in the level of sales. Furthermore, Haneda and Azizah's research (2018) shows the results that the room rent cost determined by management is determined by allocating operating costs to each room type based on the percentage of income.

At present, in calculating goods manufactured cost, the company uses a traditional system, where all costs are not directly allocated to the product on an allocation basis. All allocations are costs that are triggered due to the relationship of production volume. Based on the explanation above, it can be understood how important it is to use the ABC system in calculating the cost of production.

According to Mulyadi (2012) cost accounting is an information system that produces company operating costs and information that is used as a basis for measuring, analyzing, reporting and making decisions. According to Supriyono (2012) accounting cost is a cost information generated by company management as a basis for management decisions in achieving company goals (Wiguna, 2017).

Costs are the basic price or part of which is used or consumed to obtain income (Sunarto, 2004 \& Rahmadani et.al. 2016). Costs represent the sacrifice of economic resources to obtain goods / services that are useful for the present or the future (Siregar, 2013 \& Siby et.al. 2018).

The grouping of costs over all existing cost elements into certain groups that are more concise and can provide more concise and important information is called cost classification. Commonly used in the classification of costs related to products, production volumes, departments and cost centers, accounting periods, decision making (Siby et.al. 2018). According to Carter (2102) the cost classification is based on (Palupi et.al. 2016): (1) costs with products that include manufacturing costs and commercial costs; (2) production volumes which include variable costs, fixed costs and semi-variable costs; (3) production department which includes the department of production, services, joint and joint costs; and (4) accounting period and a decision.

The method of determining the production cost is how to calculate the cost element into the cost of production (Mulyadi, 2012). The production cost includes all direct materials, direct labor and factory overhead incurred to produce goods / services (Lasena, 2013).

Activity Based Costing System is an approach to determining product costs that impose costs on products / services based on resource consumption caused by activities (Blocher et.al., 2011). The basis of this approach is that the company's products / services are carried out by the required activities and activities using resources that cause costs. Resources are charged to cost objects based on their usefulness (Haneda et al. 2018).

\section{METHODS}

This study is using a descriptive method of case study approach, which can describe the existence of a variable, symptoms or circumstances. Using this method adjusts the ability to answer the problem under study and hopes to be able to provide clear results and answers. This study focuses on the housing construction cost according to management and calculation of the cost of housing construction using the $\mathrm{ABC}$ system. 
Application In Activity Based Costing (ABC) Calculation Of Home Development Cost (Study on Housing in Sidoarjo)

Prasetyo, Rahardjo, Supriadi, Kusmayati, \& Wahib

\section{RESULTS AND DISCUSSION}

\section{Calculation of the Building Cost a House by Company}

Determination of development cost carried out by the company that is using a traditional system, this system uses unit-level drivers. The calculations are as follows:

Table 1. Land and Construction Costs (Main Costs)

\begin{tabular}{|c|l|r|r|c|}
\hline Number & \multicolumn{1}{|c|}{ House Type } & Land Cost & $\begin{array}{c}\text { Construction } \\
\text { Costs }\end{array}$ & Total \\
\hline 1 & Home Office Type-58/90 & 77.647 .208 & 133.400 .000 & 211.047 .208 \\
\hline 2 & Type-38/90 & 77.647 .208 & 95.000 .000 & 172.647 .208 \\
\hline 3 & Type-50/91 & 78.509 .955 & 125.000 .000 & 203.509 .955 \\
\hline 4 & Type-70/120 & 103.529 .611 & 210.000 .000 & 313.529 .611 \\
\hline 5 & Type-70/135 & 116.470 .812 & 210.000 .000 & 326.470 .812 \\
\hline
\end{tabular}

Source: housing data in Sidoarjo

Table 2. Utility Costs (Overhead Costs)

\begin{tabular}{|c|l|r|}
\hline Number & \multicolumn{1}{|c|}{ Cost Type } & \multicolumn{1}{c|}{ Total } \\
\hline 1 & Land Planning Costs & 17.557 .029 .500 \\
\hline 2 & Infrastructure Costs & 11.000 .000 .000 \\
\hline 3 & Electricity cost (PLN) & 1.228 .000 .000 \\
\hline 4 & Environmental Facility Fee & 2.640 .000 .000 \\
\hline 5 & Building Planning Costs & 100.000 .000 \\
\hline 6 & Licensing Fees & 983.200 .000 \\
\hline 7 & Project Office Administration Costs & 3.840 .000 .000 \\
\hline \multicolumn{2}{|c|}{ Total cost } & $\mathbf{3 7 . 3 4 8 . 2 2 9 . 5 0 0}$ \\
\hline \multicolumn{2}{|c|}{ Number of housing units and Home Office } & 564 Unit \\
\hline \multicolumn{2}{|c|}{ Total Cost per Unit } \\
\hline
\end{tabular}

Source: housing data in Sidoarjo

Table 3. Calculation of Cost of Building Houses

\begin{tabular}{|l|l|r|r|r|r|r|}
\hline Number & Cost Type & $\begin{array}{c}\text { Home } \\
\text { Office } \\
\text { Type- } \\
\mathbf{5 8 / 9 0}\end{array}$ & $\begin{array}{c}\text { Type- } \\
\mathbf{3 8 / 9 0}\end{array}$ & $\begin{array}{c}\text { Type- } \\
\mathbf{5 0 / 9 1}\end{array}$ & $\begin{array}{c}\text { Type- } \\
\mathbf{7 0 / 1 2 0}\end{array}$ & $\begin{array}{c}\text { Type- } \\
\mathbf{7 0 / 1 3 5}\end{array}$ \\
\hline 1 & Land Cost & 77.647 .208 & 77.647 .208 & 78.509 .955 & 103.529 .611 & 116.470 .812 \\
\hline 2 & Construction Costs & 133.400 .000 & 95.000 .000 & 125.000 .000 & 210.000 .000 & 210.000 .000 \\
\hline 3 & Utility Costs & 66.220 .265 & 66.220 .265 & 66.220 .265 & 66.220 .265 & 66.220 .265 \\
\hline & Total & $\mathbf{2 7 7 . 2 6 7 . 4 7 3}$ & $\mathbf{2 3 8 . 8 6 7 . 4 7 3}$ & $\mathbf{2 6 9 . 7 3 0 . 2 2 0}$ & $\mathbf{3 7 9 . 7 4 9 . 8 7 6}$ & $\mathbf{3 9 2 . 6 9 1 . 0 7 7}$ \\
\hline
\end{tabular}

Source: housing data in Sidoarjo

\section{Calculation of the Cost of House Construction Based on the ABC System}

Determination of housing construction basic cost with the traditional system as stated above does not provide accurate information because it causes distortion between types of houses. $\mathrm{ABC}$ system is one method that can produce accurate information because there is a charge for each activity. The calculations are as follows:

Table 4. Utility Costs (Overhead Costs)

\begin{tabular}{|c|l|r|}
\hline Number & \multicolumn{1}{|c|}{ Cost Type } & \multicolumn{1}{c|}{ Total } \\
\hline 1 & Land Planning Costs & 17.557 .029 .500 \\
\hline 2 & Infrastructure Costs & 11.000 .000 .000 \\
\hline 3 & Electricity cost (PLN) & 1.228 .000 .000 \\
\hline 4 & Environmental Facility Fee & 2.640 .000 .000 \\
\hline 5 & Building Planning Costs & 100.000 .000 \\
\hline
\end{tabular}


Application In Activity Based Costing (ABC) Calculation Of Home Development Cost (Study on Housing in Sidoarjo) Prasetyo, Rahardjo, Supriadi, Kusmayati, \& Wahib

\begin{tabular}{|c|l|r|}
\hline Number & Cost Type & \multicolumn{1}{|c|}{ Total } \\
\hline 6 & Licensing Fees & 983.200 .000 \\
\hline 7 & Project Office Administration Costs & 3.840 .000 .000 \\
\hline \multicolumn{2}{|c|}{ Total Cost } & $\mathbf{3 7 . 3 4 8 . 2 2 9 . 5 0 0}$ \\
\hline
\end{tabular}

Source: housing data in Sidoarjo

Table 5. Activity Identification

\begin{tabular}{|c|l|c|}
\hline Number & \multicolumn{1}{|c|}{ Cost Type } & Activity \\
\hline 1 & Land Planning Costs & Batch Level \\
\hline 2 & Infrastructure Costs & Batch Level \\
\hline 3 & Electricity cost (PLN) & Batch Level \\
\hline 4 & Environmental Facility Fee & Batch Level \\
\hline 5 & Building Planning Costs & Product Level \\
\hline 6 & Licensing Fees & Product Level \\
\hline 7 & Project Office Administration Costs & Product Level \\
\hline
\end{tabular}

Source: processed data

Table 6. Grouping of Costs to Activities

\begin{tabular}{|c|l|r|}
\hline Number & \multicolumn{1}{|c|}{ Cost Type } & \multicolumn{1}{c|}{ Total } \\
\hline 1 & Unit Level Activity Costs & 1.228 .000 .000 \\
\hline & Electricity cost (PLN) & $\mathbf{1 . 2 2 8 . 0 0 0 . 0 0 0}$ \\
\hline & Total & \\
\hline & & 17.557 .029 .500 \\
\hline 2 & Batch Level Activity Costs & 11.000 .000 .000 \\
\hline & Land Planning Costs & 2.640 .000 .000 \\
\hline & Infrastructure Costs & $\mathbf{3 1 . 1 9 7 . 0 2 9 . 5 0 0}$ \\
\hline & Environmental Facility Fee & \\
\hline & Total & 100.000 .000 \\
\hline & & 983.200 .000 \\
\hline 3 & Product Level Activity Costs & 3.840 .000 .000 \\
\hline & Land Planning Costs & $\mathbf{4 . 9 2 3 . 2 0 0 . 0 0 0}$ \\
\hline & Licensing Fees & \\
\hline & Project Office Administration Costs & \\
\hline & Total &
\end{tabular}

Source: processed data

Table 7. Determination of Drivers for Activities

\begin{tabular}{|c|l|c|}
\hline Number & \multicolumn{1}{|c|}{ Cost Type } & Activity \\
\hline 1 & Land Planning Costs & Land area \\
\hline 2 & Infrastructure Costs & Land area \\
\hline 3 & Electricity cost (PLN) & Number of units \\
\hline 4 & Environmental Facility Fee & Land area \\
\hline 5 & Land Planning Costs & Building Area \\
\hline 6 & Licensing Fees & Building Area \\
\hline 7 & Project Office Administration Costs & Building Area \\
\hline
\end{tabular}

Source: processed data

Table 8. Calculation of Activity Group Rates

\begin{tabular}{|c|l|c|c|c|}
\hline Number & \multicolumn{1}{|c|}{ Cost Type } & Cost & Driver & Pool Rate \\
\hline 1 & Unit Level Activity Costs & & & \\
\hline & Electricity cost (PLN) & 1.228 .000 .000 & 564 unit & 2.177 .305 \\
\hline & & & & \\
\hline 2 & Batch Level Activity Costs & & & \\
\hline
\end{tabular}

182 | Ilomata International Journal of Tax and Accounting 
Application In Activity Based Costing (ABC) Calculation Of Home Development Cost (Study on Housing in Sidoarjo) Prasetyo, Rahardjo, Supriadi, Kusmayati, \& Wahib

\begin{tabular}{|c|c|c|c|c|}
\hline & Land Planning Costs & \multirow{3}{*}{31.197 .029 .500} & \multirow{3}{*}{$\begin{array}{c}60.541 \mathrm{M}^{2} \\
\text { Effective } \\
\text { Land Area }\end{array}$} & \multirow{3}{*}{515.302} \\
\hline & Infrastructure Costs & & & \\
\hline & Environmental Facility Fee & & & \\
\hline \multirow[t]{4}{*}{3} & Product Level Activity Costs & & & \\
\hline & Land Planning Costs & \multirow{3}{*}{4.923 .200 .000} & \multirow{3}{*}{$\begin{array}{c}28.040 \mathrm{M}^{2} \\
\text { Effective } \\
\text { Building Area }\end{array}$} & \multirow{3}{*}{175.578} \\
\hline & Licensing Fees & & & \\
\hline & $\begin{array}{l}\text { Project Office Administration } \\
\text { Costs }\end{array}$ & & & \\
\hline
\end{tabular}

Source: processed data

Table 9. Calculation of the Cost of Building Houses with the ABC System

\begin{tabular}{|l|l|r|r|r|r|r|}
\hline Number & Total Cost & $\begin{array}{c}\text { Home Office } \\
\text { Type-58/90 }\end{array}$ & Type-38/90 & Type-50/91 & \multicolumn{1}{c|}{$\begin{array}{c}\text { Type- } \\
\mathbf{7 0 / 1 2 0}\end{array}$} & \multicolumn{1}{c|}{$\begin{array}{c}\text { Type- } \\
\mathbf{7 0 / 1 3 5}\end{array}$} \\
\hline 1 & Land Cost & 77.647 .208 & 77.647 .208 & 78.509 .955 & 103.529 .611 & 116.470 .812 \\
\hline 2 & $\begin{array}{l}\text { Construction } \\
\text { Costs }\end{array}$ & 133.400 .000 & 95.000 .000 & 125.000 .000 & 210.000 .000 & 210.000 .000 \\
\hline 3 & Utility Costs & & & & & \\
\hline & Unit Level & 2.177 .305 & 2.177 .305 & 2.177 .305 & 2.177 .305 & 2.177 .305 \\
\hline & Batch Level & 46.377 .222 & 46.377 .222 & 46.892 .524 & 61.836 .296 & 69.565 .833 \\
\hline \multicolumn{2}{r|}{ Product Level } & 10.183 .509 & 6.671 .954 & 8.778 .887 & 12.290 .442 & 12.290 .442 \\
\hline \multicolumn{2}{r|}{ Total } & $\mathbf{2 6 9 . 7 8 5 . 2 4 4}$ & $\mathbf{2 2 7 . 8 7 3 . 6 8 9}$ & $\mathbf{2 6 1 . 3 5 8 . 6 7 1}$ & $\mathbf{3 8 9 . 8 3 3 . 6 5 4}$ & $\mathbf{4 1 0 . 5 0 4 . 3 9 2}$ \\
\hline
\end{tabular}

Source: housing data in Sidoarjo

Table 10. Comparison of Company Calculations with ABC systems

\begin{tabular}{|c|l|r|r|r|c|}
\hline Number & \multicolumn{1}{|c|}{ House Type } & Traditional & \multicolumn{1}{|c|}{ ABC System } & \multicolumn{1}{c|}{ Gap } & Percentage \\
\hline 1 & Home Office Type-58/90 & 277.267 .473 & 269.785 .244 & -7.482 .229 & $-3 \%$ \\
\hline 2 & Type-38/90 & 238.867 .473 & 227.873 .689 & -10.993 .784 & $-5 \%$ \\
\hline 3 & Type-50/91 & 269.730 .220 & 261.358 .671 & -8.371 .549 & $-3 \%$ \\
\hline 4 & Type-70/120 & 379.749 .876 & 389.833 .654 & 10.083 .778 & $3 \%$ \\
\hline 5 & Type-70/135 & 392.691 .077 & 410.504 .392 & 17.813 .315 & $4 \%$ \\
\hline
\end{tabular}

Source: housing data in Sidoarjo

\section{CONCLUSION}

The results of the calculation of housing construction cost using the $\mathrm{ABC}$ system on housing in Sidoarjo are able to describe the results more accurately and do not cause distortion of costs. This system can improve decision making planning so that it can help management in improving its financial planning.

\section{REFERENCES}

Al-Saidi, Shafeq Hamoud., \& H. Nanje Gowda. (2014). Measures for Activity Based Costing Success: A Review, International Journal of Research in Commerce, IT and Management, Vol.4, Issue No.5, May, pp. 10-13.

Blocher, Edward J., David E Stout., \& Gary Cokin. (2011). Cost Management: Strategic Emphasis, Translated by David Wijaya, Jakarta, Salemba Empat.

Carter, William K.. (2012). Cost Accounting Fourteenth Edition, Book 1, Jakarta, Salemba Empat.

Farzanesh, Nassizadeh., Saei Mohammad Javad., Salehi Nahdi., \& Bayegi Sayyed Ali Haddad. (2010). A Study of the Stickiness of Costs of Goods Sold and Operating Costs to Changes in Sales Level in Iran, Studies in Business and Economics, pp. 79-89. 
Haneda, Nivo, \& Devi Farah Azizah. (2018). Analysis of the Calculation of Cost of Room for Rent with an Activity Based Costing System (Study at Hasanah Buring Guest House in Malang City 2016), Journal of Business Administration, Vol.56, No.1, March, Pg. 48-56.

Joseph, C. Samuel., F.J. Peter Kumar., \& R. Magesh Kumar. (2019). Implementing Activity Based Costing Among Automotive Engineering Industries in the Small and Medium Enterprises Sector of Tamil Nadu, International Journal of Mechanical Engineering and Technology (IJMET), Vol.10, Issue 01, January, pp. 550-563.

Lasena, Sity Rahmi. (2013). Analysis of Determination of Cost of Production at PT. Dimembe Nyiur Agripro, EMBA Journal, Vol.1, No.3, Juni, Pg. 585-592.

Martusa, R.., S.R. Darma., \& V. Carolina. (2010). The Role of the Activity Based Costing Method in determining the Cost of Goods Manufactured. Accurate Accounting Scientific Journal, No.1, 1st Year, May-August, pp.39-60.

Mulyadi. (2012). Cost Accounting, Issue 5, Yogyakarta, UPP STIM YKPN.

Palupi, Tiara Ayu., Zahroh Z.A., \& M.G. Wi Endang NP., (2016). Analysis of Standard Costs to Support the Efficiency of Company Production Costs (Study in Sustainable Sugar Mills, Patianrowo, Nganjuk), Journal of Business Administration (JAB), Vol. 36, No.1, July, Pg. 80-85.

Rahmadani, Nurfatimah, \& Andi Wawo. (2016). Determination of the Cost of Home Building Production Using the Activity Based Costing Method (Study in Perumnas Regional VII Makassar), Scientific Journal of Civilization Accounting, Vol.2, No.1, July, Pg. 108-128.

Siby, Shelby Estereniy., Ventje Ilat., \& Meily Y.B. Kalalo. (2018). Implementation of Activity Based Costing System in Determining Cost of Hotel Rooms (Study at Manado Green Eden Hotel), Journal of Accounting Research Going Concern, Vol.13, No.2, Pg. 140-148.

Siregar, Baldric, et.al., (2013). Management Accounting, Jakarta, Salemba Empat.

Sunarto (2004). Cost Accounting, Revised Edition, Yogyakarta, AMUS.

Supriyono. (2012). Cost Accounting, Yogyakarta, BPFE.

Wiguna, I Gd Nandra Hary. (2017). Activity Based Costing System as an alternative to the Determination of Inpatient Services Rates and Their Implications for Revenue of Buleleng District Hospital, Scientific Journal of Accounting, Vol.2, No.2, December, pp.148-172. 